\title{
PENERAPAN DIAGRAM KENDALI MAXIMUM MULTIVARIATE CUMULATIVE SUM (MAX-MCUSUM) PADA PENGENDALIAN KUALITAS PRODUK KACANG (Studi Kasus: Produk Kacang Garing di PT XY)
}

\author{
Sintia Rizki Aprilianti ${ }^{1}$, Tatik Widiharih ${ }^{2}$, Sudarno $^{3}$ \\ ${ }^{1,2,3}$ Departemen Statistika, Fakultas Sains dan Matematika, Universitas Diponegoro \\ E-mail: sintiarizki@ students.undip.ac.id
}

\begin{abstract}
Now, Statistical quality control be a particular concern to large companies.PT XY is one of the largest nut company in Indonesia that has implemented the quality standards of a product. Max-MCUSUM control chart becomes a tool that is graphically used to monitor and evaluate whether the process is under control or nut. Based on Cheng and Thaga (2005), Max-MCUSUM control chart takes precedence over detecting small shift based on average and variability in industry data. The quality characteristic of Kacang Garing will be variables, namely broken nut skin, bean seed 1, and foam nut skin. Max-MCUSUM control chart is controlled with the control limit (h) from ARL (Average Run Length) simulation of 370 is 429,69. ARL is an average of samples that need to be decribed before it goes out of control. The research continued with multivariate capability process with MCp worth 0,905 and MCpk worth 1,355. Those value indicates that Kacang Garing has met the quality specification stipulated by PT XY. Broken nut skin becomes the most dominant cause based on pareto chart and carried out analysis by using fishbone chart so that is known the main factor causing broken nut skin are machine, material, and method.
\end{abstract}

Keywords: Max-MCUSUM, Capability Process, Pareto Chart, Fishbone Chart.

\section{PENDAHULUAN}

Kacang Garing merupakan salah satu produk utama yang diproduksi oleh PT XY. Terdapat tiga kualitas kacang yang diprodusi dan salah satunya adalah kualitas first grade. Proses produksi Kacang Garing first grade dilakukan menggunakan mesin dari proses penerimaan kacang basah hingga proses pengemasan. Adanya defect pada kacang garing first grade yang ditemukan pada proses sortasi final sebagian besar dipengaruhi oleh mesin. Dalam menindaklanjuti masalah tersebut, perlu adanya usaha pengendalian proses dan pengendalian produk supaya proses produksi berjalan lancar dan produk yang dihasilkan mempunyai kualitas yang diinginkan.

Pengendalian kualitas Statistika merupakan metode yang digunakan untuk mengetahui apakah suatu proses produksi sudah terkendali atau tidak. Grafik pengendali mampu memberikan informasi tentang kemampuan proses serta memberikan nilai parameter proses dan stabilitas dari waktu ke waktu. Hal ini biasanya menaksir parameter suatu proses produksi sehingga menentukan kemampuan dan memberikan informasi yang berguna dalam meningkatkan proses (Montgomery, 2009).

Diagram kendali multivariat digunakan apabila terdapat korelasi antar variabel dalam penelitian ini. Diagram kendali multivariat yang akan digunakan adalah peta kendali Maximum Multivariate Cumulative Sum (Max-MCUSUM). Diagram kendali MaxMCUSUM adalah diagram kendali yang dapat digunakan untuk mendeteksi pergeseran proses baik pada rata-rata maupun variabilitas proses dalam satu diagram kendali. Menurut Cheng dan Thaga (2005), diagram kendali tersebut lebih diutamakan untuk mendeteksi perubahan kecil berdasarkan rata-rata ataupun variabilitas pada data industri dalam pengendalian kualitas sebuah produk. Analisis dilanjutkan dengan analisis kapabilitas proses, dan ditelusuri parameter penyumbang kecacatan terbesar dalam proses untuk dicari penyebabnya. 


\section{TINJAUAN PUSTAKA}

\subsection{Kualitas Kacang Garing}

Produk Kacang Garing kualitas first grade memiliki tiga kualitas utama (mayor) yang menjadi perhatian perusahaan, yakni kulit kacang pecah, kacang biji 1, dan kulit kacang busam $\geq 50 \%$. Pemilihan atribut mutu tersebut dikarenakan atribut ini memberikan pengaruh yang signifikan kepada kualitas produk yang dihasilkan

\subsection{Pengendalian Kualitas Statistik}

Pengertian pengendalian kualitas menurut Assauri (1998) adalah pengawasan mutu, usaha untuk mempertahankan mutu atau kualitas dari barang yang dihasilkan agar sesuai dengan spesifikasi produk yang telah ditetapkan. Sedangkan pegendalian kualitas statistik merupakan suatu alat yang dapat digunakan untuk mengurangi biaya, menurunkan cacat, dan meningkatkan kualitas pada proses manufacturing.

\subsection{Data Multivariat}

Menurut Haryatmi dan Guritno (2008), data yang diperoleh dengan mengukur lebih dari satu variabel kriteria pada setiap individu anggota sampel disebut data multivariat. Teknikteknik analisis statistik yang memperlakukan sekelompok variabel kriteria yang saling berkolasi sebagai suatu sistem dengan memperhitungkan korelasi antar variabel-variabel tersebut disebut metode statistika multivariat.

Tabel 1. Struktur Data Multivariat

\begin{tabular}{llllll}
\hline \multirow{2}{*}{ Variate } & \multicolumn{5}{c}{ Objek } \\
\cline { 2 - 6 } & $\mathbf{1}$ & $\ldots$ & $\mathbf{J}$ & $\ldots$ & $\mathbf{n}$ \\
\hline $\mathrm{X}_{1}$ & $\mathrm{X}_{11}$ & $\ldots$ & $\mathrm{X}_{1 \mathrm{j}}$ & $\ldots$ & $\mathrm{X}_{1 \mathrm{n}}$ \\
$\mathrm{X}_{2}$ & $\mathrm{X}_{21}$ & $\ldots$ & $\mathrm{X}_{2 \mathrm{j}}$ & $\ldots$ & $\mathrm{X}_{2 \mathrm{n}}$ \\
$\ldots$ & $\ldots$ & $\ldots$ & $\ldots$ & $\ldots$ & $\ldots$ \\
$\mathrm{X}_{\mathrm{i}}$ & $\mathrm{X}_{\mathrm{i} 1}$ & $\ldots$ & $\mathrm{X}_{\mathrm{ij}}$ & $\ldots$ & $\mathrm{X}_{\mathrm{in}}$ \\
$\ldots$ & $\ldots$ & $\ldots$ & $\ldots$ & $\ldots$ & $\ldots$ \\
$\mathrm{X}_{\mathrm{p}}$ & $\mathrm{X}_{\mathrm{p} 1}$ & $\ldots$ & $\mathrm{X}_{\mathrm{pj}}$ & $\ldots$ & $\mathrm{X}_{\mathrm{pn}}$ \\
\hline
\end{tabular}

$X_{i j}$ merupakan pengamatan variat ke-i pada objek ke-j, dengan $i=1,2,3, \ldots, p$ dan $j=$ $1,2,3, \ldots, \mathrm{n}$.

\subsection{Korelasi}

Uji korelasi dilakukan terhadap variabel kulit kacang pecah, kacang biji 1, dan kulit kacang busam dengan pengujian Bartlett yaitu sebagai berikut.

Hipotesis:

$\mathrm{H}_{0} \quad: \mathbf{R}=\mathbf{I}$ (tidak terdapat korelasi antar variabel)

$\mathrm{H}_{1} \quad: \mathbf{R} \neq \mathbf{I}$ (terdapat korelasi antar variabel)

Statistik uji:

$\chi_{\text {hitung }}^{2}=-\left\{n-1-\frac{2 p+5}{6}\right\} \ln |\boldsymbol{R}|$

dimana:

$\mathrm{n}=$ banyaknya observasi

$\mathrm{p}=$ banyaknya karakteristik kualitas

$\mathbf{R}=$ matriks korelasi dari masing-masing variabel

$\mathbf{I}=$ matriks identitas

Kriteria uji :

$\mathrm{H}_{0}$ diterima apabila $\chi_{\text {hitung }}^{2}<\chi_{\alpha, \frac{1}{2} p(p-1)}^{2}$.

\subsection{Uji Distribusi Normal Multivariat}

Uji distribusi normal multivariat dilakukan dengan pengujian Mardia yaitu sebagai berikut. 
Hipotesis:

$\mathrm{H}_{0} \quad: x_{1}, x_{2}, \ldots, x_{p}$ berdistribusi normal multivariat

$\mathrm{H}_{1} \quad: x_{1}, x_{2}, \ldots, x_{p}$ tidak berdistribusi normal multivariat

Statistik uji:

$b_{1, p}=\frac{1}{n^{2}} \sum_{i=1}^{n} \sum_{j=1}^{n} \boldsymbol{m}_{i j}^{3}$

$b_{2, p}=\frac{1}{n} \sum_{i=1}^{n} \boldsymbol{m}_{i i}^{2}$

$z_{1, p}=\frac{n}{6} b_{1, p}$

$z_{2, p}=\frac{b_{2, p}-[p(p+2)(n-1)] /(n+1)}{\sqrt{8 p(p+2) / n}}$

dimana:

$\mathrm{p}$ : variabel penelitian

$b_{1, p}=$ multivariate skewness

$b_{2, p}=$ multivariate kurtosis

$\boldsymbol{m}_{i j}=\left(\boldsymbol{x}_{i}-\overline{\boldsymbol{x}}\right)^{\prime} \boldsymbol{S}^{-1}\left(\boldsymbol{x}_{j}-\overline{\boldsymbol{x}}\right)$,

$\boldsymbol{m}_{i i}=\left(\boldsymbol{x}_{i}-\overline{\boldsymbol{x}}\right)^{\prime} \boldsymbol{S}^{-1}\left(\boldsymbol{x}_{i}-\overline{\boldsymbol{x}}\right)$,

$\boldsymbol{x}_{\boldsymbol{i}}=$ vektor pengamatan ke-i dengan $\mathrm{i}=1,2, \ldots, \mathrm{n}$

$\boldsymbol{x}_{\boldsymbol{j}}=$ vektor pengamatan ke-j dengan $\mathrm{j}=1,2, \ldots, \mathrm{n}$

$\overline{\boldsymbol{x}}=$ vektor rata-rata berukuran $3 \mathrm{x} 1$

$\boldsymbol{S}=$ matriks varian kovarian berukuran $3 \times 3$

Kriteria uji: 2017).

$\mathrm{H}_{0}$ diterima apabila nilai $z_{1, p}<\chi_{p(p+1)(p+2) / 6}^{2}$ dan nilai $z_{2, p}<Z_{\alpha / 2}$ (Meghan et al,

\subsection{Diagram Kontrol Cumulative Sum}

Diagram control CUSUM pertama kali diteliti oleh Page di tahun 1954 (Montgomery, 2013). Diagram control CUSUM lebih baik digunakan untuk mendeteksi pergeseran kecil pada rata-rata atau varian dalam proses, yang disebabkan adanya assignable cause atau penyebab khusus. Prosedur CUSUM memberikan tanda bahwa pergeseran terjadi segera setelah:

$$
S_{i}=\sum_{i=1}^{n} \log \frac{f_{B}\left(x_{i}\right)}{f_{G}\left(x_{i}\right)}-\min \sum_{i=1}^{k} \log \frac{f_{B}\left(x_{i}\right)}{f_{G}\left(x_{i}\right)}>h, i=1,2, \ldots, n .
$$

$\mathrm{F}_{\mathrm{G}}$ dan $\mathrm{F}_{\mathrm{B}}$ diasumsikan berdistribusi normal multivariat. Nilai konstan $\mathrm{h}$ merupakan batas atas grafik pengendali yang dapat didekati dengan kriteria nilai ARL. Melalui uji probabilitas rasio pada umumnya, nilai konstan h tidak bergantung oleh nilai $n$. Nilai $S_{n}$ dapat dihitung menggunakan:

$$
S_{i}=\max \left(0 ; \quad S_{n-1}+\log \frac{f_{B}\left(x_{i}\right)}{f_{G}\left(x_{i}\right)}\right) .
$$

Nilai awal peta kendali CUSUM yang ditentukan adalah $S_{0}=0$. Pada setiap periode, statistik CUSUM dibandingkan dengan interval keputusan tetap $h$ dan jika lebih dari $h$ berarti terjadi pergeseran proses. Setelah pendeteksian pergeseran dan tindakan perbaikan dilakukan, statistik CUSUM di-reset ke nilai awal $\mathrm{S}_{0}=0$.

\subsection{Diagram Kontrol Max-MCUSUM}

Pada diagram kontrol Max-MCUSUM diasumsikan bahwa $\mathbf{X}_{\mathbf{i}}$ berasal dari distribusi normal multivariat, dengan rata-rata $\boldsymbol{\mu}_{\mathbf{G}}$ yaitu ketika proses terkendali, dan rata-rata buruk $\boldsymbol{\mu}_{\mathbf{B}}$ yaitu ketika proses tidak terkendali dimana $\boldsymbol{\mu}_{\mathbf{B}}=\boldsymbol{\mu}_{\mathbf{G}}+\boldsymbol{\delta}$ dan dengan matriks kovarians umum yang diketahui $\boldsymbol{\Sigma}$. Jika setiap variabel random normal multivariat $\mathbf{X}_{\mathbf{i}}$, dapat dihitung karakteristik kualitas sebanyak $p$, sebuah vektor berukuran $p \times 1$ terbentuk dari sebuah matriks varian kovarians dengan ukuran $p$ x $p$ juga terbentuk. 


\subsubsection{Maximum Multivariate Cumulative Sum (Max-MCUSUM) untuk Rata-rata}

$\mathrm{F}_{\mathrm{G}}$ dan $\mathrm{F}_{\mathrm{B}}$ diasumsikan berdistribusi normal multivariat dan memiliki matriks kovarian yang sama, maka peta kendali CUSUM dikembangkan melalui persamaan rasio likelihood, yaitu sebagai berikut:

$$
\begin{aligned}
& \frac{f_{B}\left(x_{i}\right)}{f_{G}\left(x_{i}\right)}=\frac{(2 \pi)^{-p / 2}|\boldsymbol{\Sigma}|^{-1 / 2} \exp \left(-0.5\left(\boldsymbol{X}_{i}-\boldsymbol{\mu}_{B}\right)^{\prime} \boldsymbol{\Sigma}^{-1}\left(\boldsymbol{X}_{i}-\boldsymbol{\mu}_{B}\right)\right)}{(2 \pi)^{-p / 2}|\boldsymbol{\Sigma}|^{-1 / 2} \exp \left(-0.5\left(\boldsymbol{X}_{i}-\boldsymbol{\mu}_{G}\right)^{\prime} \boldsymbol{\Sigma}^{-1}\left(\boldsymbol{X}_{i}-\boldsymbol{\mu}_{G}\right)\right)} \\
& \log \frac{f_{B}\left(x_{i}\right)}{f_{G}\left(x_{i}\right)}=\left(\boldsymbol{\mu}_{B}-\boldsymbol{\mu}_{G}\right)^{\prime} \boldsymbol{\Sigma}^{-1} \boldsymbol{X}_{i}-0.5\left(\boldsymbol{\mu}_{B}+\boldsymbol{\mu}_{G}\right)^{\prime} \boldsymbol{\Sigma}^{-1}\left(\boldsymbol{\mu}_{B}-\boldsymbol{\mu}_{G}\right)
\end{aligned}
$$

Diketahui prosedur CUSUM untuk proses multivariat sebagai berikut,

$$
\begin{aligned}
& C_{i}=\max \left(C_{i-1}+\boldsymbol{a}^{\prime} \boldsymbol{X}_{\boldsymbol{i}}-\boldsymbol{k} ; 0\right)>h, i=1,2, \ldots, n \\
& \text { dengan } \mathrm{C}_{0}=0 \text {, dengan } \boldsymbol{a}^{\prime}=\frac{\left(\boldsymbol{\mu}_{B}-\boldsymbol{\mu}_{G}\right) \boldsymbol{\Sigma}^{-1}}{\left[\left(\boldsymbol{\mu}_{B}-\boldsymbol{\mu}_{G}\right) \boldsymbol{\Sigma}^{-\mathbf{1}}\left(\boldsymbol{\mu}_{B}-\boldsymbol{\mu}_{G}\right)\right]^{\mathbf{1 / 2}}},
\end{aligned}
$$

$$
k=0.5 \frac{\left(\boldsymbol{\mu}_{B}+\boldsymbol{\mu}_{G}\right) / \boldsymbol{\Sigma}^{-1}\left(\boldsymbol{\mu}_{B}-\boldsymbol{\mu}_{G}\right)}{\left[\left(\boldsymbol{\mu}_{B}-\boldsymbol{\mu}_{G}\right) / \boldsymbol{\Sigma}^{-1}\left(\boldsymbol{\mu}_{B}-\boldsymbol{\mu}_{G}\right)\right]^{1 / 2}},
$$

Sekarang, variabel random $\boldsymbol{a}^{\prime} \boldsymbol{X}_{i}$ memiliki distribusi normal univariat. Parameter noncentrality ditentukan sebagai,

$$
\begin{aligned}
& D=\sqrt{\left(\boldsymbol{\mu}_{B}-\boldsymbol{\mu}_{G}\right)^{\prime} \boldsymbol{\Sigma}^{-\mathbf{1}}\left(\boldsymbol{\mu}_{B}-\boldsymbol{\mu}_{G}\right)}, \\
& Z_{i}=\boldsymbol{a}^{\prime}\left(\boldsymbol{X}_{i}-\boldsymbol{\mu}_{G}\right) .
\end{aligned}
$$

Peta kendali CUSUM untuk mendeteksi pergeseran pada vektor mean proses normal multivariat dapat ditulis sebagai berikut.

$$
C_{i}=\max \left(0 ; C_{i-1}+Z_{i}-0.5 D\right)>h .
$$

\subsubsection{Maximum Multivariate Cumulative Sum (Max-MCUSUM) untuk Varian}

Pergeseran tipe ini dapat muncul ketika sesuatu terjadi pada proses manufaktur yang mempengaruhi semua variabel proses. Rasio likelihood yang diberikan adalah sebagai berikut,

$$
\begin{aligned}
& \frac{f_{B}\left(x_{i}\right)}{f_{G}\left(x_{i}\right)}=\frac{(2 \pi)^{-p / 2}|\mathbf{b} \boldsymbol{\Sigma}|^{-1 / 2} \exp \left(-0.5\left(\boldsymbol{X}_{i}-\boldsymbol{\mu}\right)^{\prime}\left(b \boldsymbol{\Sigma}^{-\mathbf{1}}\right)\left(\boldsymbol{X}_{i}-\boldsymbol{\mu}\right)\right)}{(2 \pi)^{-p / 2}|\boldsymbol{\Sigma}|^{-1 / 2} \exp \left(-0.5\left(\boldsymbol{X}_{i}-\boldsymbol{\mu}\right)^{\prime} \boldsymbol{\Sigma}^{-1}\left(\boldsymbol{X}_{i}-\boldsymbol{\mu}\right)\right)} . \\
& \log \frac{f_{B}\left(x_{i}\right)}{f_{G}\left(x_{i}\right)}=-\frac{1}{2} \log b+0.5\left(\boldsymbol{X}_{i}-\boldsymbol{\mu}\right)^{\prime} \Sigma^{-1}\left(\boldsymbol{X}_{i}-\boldsymbol{\mu}\right)\left(1-\frac{1}{b}\right) .
\end{aligned}
$$

Peta kendali CUSUM untuk mendeteksi suatu pergeseran pada variabilitas dari suatu proses yang normal multivariat dapat ditulis sebagai berikut,

$$
\begin{aligned}
& S_{i}=\max \left(S_{i-1}+\left(\boldsymbol{X}_{i}-\boldsymbol{\mu}\right)^{\prime} \boldsymbol{\Sigma}^{-1}\left(\boldsymbol{X}_{i}-\boldsymbol{\mu}\right)-v ; 0\right)>h, i=1,2, \ldots, \\
& \text { dengan } S_{o}=0, \text { dengan } v=\log (b)\left(\frac{b}{b-1}\right)
\end{aligned}
$$

Menurut Muirhead (1982), telah menunjukkan bahwa $\left(\boldsymbol{X}_{i}-\boldsymbol{\mu}\right)^{\prime} \Sigma^{-1}\left(\boldsymbol{X}_{i}-\boldsymbol{\mu}\right)$ mengikuti distribusi chi-square dengan derajat bebas $p$. Peta kendali CUSUM multivariat akan dikembangkan untuk dapat memonitor vektor mean dan matriks kovarians, dibuat transformasinya sebagai berikut, $Y_{i}=\phi^{-1}\left\{H\left[\left(\boldsymbol{X}_{i}-\boldsymbol{\mu}\right)^{\prime} \mathrm{S}^{-1}\left(\boldsymbol{X}_{i}-\boldsymbol{\mu}\right): p\right]\right\}$,

di mana $\phi(z)=P(Z \leq Z)$, dengan $Z \sim \mathrm{N}(0,1)$, berdistribusi normal standar. Fungsi $\phi^{-1}$ adalah invers dari fungsi distribusi kumulatif normal standar dan $H(w ; p)=P(W \leq$ $w \mid p)$ untuk $\mathrm{W} \sim \chi_{p}^{2}$ distribusi chi-square dengan derajat bebas $p$. Fungsi $\mathrm{Z}_{\mathrm{i}}$ dan $\mathrm{Y}_{\mathrm{i}}$ pada persamaan (2.19) dan (2.25) adalah independent dan ketika rata-rata proses dan variabilitas proses terkendali maka $\delta=0$ dan $\mathrm{b}=1$, keduanya mengikuti distribusi normal standar univariat dan distribusi tersebut tidak tergantung pada ukuran sampel (Cheng dan Thaga, 2005).

\subsubsection{Pembentukan Diagram Kontrol Max-MCUSUM}

Pergeseran proses yang mengakibatkan digram kontrol tidak terkendali dapat dikeranakan pergeseran rata-rata ataupun pergeseran varian. Berdasarkan pembahasan dua poin diatas, $Z_{i}$ dan $Y_{i}$ memiliki distribusi yang sama, dapat dibuat suatu peta kendali CUSUM yang dapat memonitor secara simultan baik rata-rata proses maupun variabilitas proses 
menggunakan satu peta kendali. Statistik CUSUM berdasarkan independensi dan distribusi normal variable $\mathrm{Z}_{\mathrm{i}}$ dan $\mathrm{Y}_{\mathrm{i}}$, diberikan sebagai berikut.

$$
\begin{aligned}
& C_{i}^{+}=\max \left(0 ; Z_{i}-0.5 D+C_{i-1}^{+}\right), \\
& C_{i}^{-}=\max \left(0 ;-0.5 D-Z_{i}+C_{(i-1)}^{-}\right), \\
& \text {untuk memonitor rata-rata proses. } \\
& S_{i}^{+}=\max \left(0 ; Y_{i}-k+S_{(i-1)}^{+}\right), \\
& S_{i}^{-}=\max \left(0 ;-k-Y_{i}+S_{i-1}^{-}\right),
\end{aligned}
$$

untuk memonitor variabilitas proses, dengan $\mathrm{C}_{0}=0$ dan $\mathrm{S}_{0}=0$ sebagai titik awal. Karena pada prosedur pengendalian kualitas multivariat dilakukan monitoring pada besarnya pergeseran bukan arahnya, statistik CUSUM di atas akan ditransformasi ke statistik berikut ini.

$$
\begin{aligned}
& C_{i}=\max \left(C_{i}^{+} ; C_{i}^{-}\right) \\
& S_{i}=\max \left(S_{i}^{+} ; S_{i}^{-}\right)
\end{aligned}
$$

Karena $Z_{i}$ dan $Y_{i}$ mengikuti distribusi yang sama, statistic untuk peta kendali multivariat dapat dikembangkan dengan menjadi sebagai berikut:

$$
M_{i}=\max \left(C_{i} ; S_{i}\right)
$$

Nilai $M_{i}$ menjadi titik yang diplotkan dalam grafik kendali. Karena $M_{i} \geq 0$ maka hanya digunakan batas control atas atau upper control limit (h) (Raissi, 2009). Jika $M_{i}>\mathrm{h}$, maka peta kendali akan memperlihatkan proses tidak terkendali, dimana $\mathrm{h}>0$ dipilih untuk mendapatkan nilai terkendali melalui ARL.

\subsection{Kapabilitas Proses}

Analisis kapabilitas proses merupakan analisis yang dilakukan untuk mengukur kemampuan proses pada suatu produk dalam memenuhi spesifikasi yang ditentukan (Montgomery, 2013). Indeks dapat dihitung menggunakan persamaan sebagai berikut (Raissi, 2009).

$$
\begin{aligned}
& M C_{p}=\sum_{i=1}^{n} w_{i} C_{p}\left(X_{i}\right) \\
& M C_{p k}=\sum_{i=1}^{n} w_{i} C_{p k}\left(X_{i}\right)
\end{aligned}
$$

$M C_{p}$ dan $M C_{p k}$ berturut-turut merupakan bentuk multivariat dari $C_{p}$ dan $C_{p k}$ dengan $w_{i}$ merupakan pembobot berdasarkan kepentingan dengan $\sum_{i=1}^{n} w_{i}=1$, serta $\mathrm{n}$ merupakan banyak karakteristik kualitas dalam pengamatan.

\subsection{Diagram Pareto}

Diagram pareto terbentuk oleh jenis kecacatan sebagai sumbu-x dan banyaknya cacat yang terjadi sebagai sumbu-y. Diagram batang akan merefleksikan banyaknya kecacatan untuk setiap jenis cacat, sedangkan untuk diagram garis akan merefleksikan presentase kumulatif kecacatan (Wilkinson, 2006).

\subsection{Diagram Sebab-akibat}

Diagram sebab-akibat disusun oleh tulang utama yang merupakan kategori utama penyebab sebuah kecacatan yang meliputi metode, mesin, sumber daya manusia, bahan baku, pengukuran, ataupun lingkungan. Setiap kategori utama akan diamati lebih dalam untuk melihat kemungkinan penyebab dari setiap kategori yang ada. Penyebab dari setiap kategori utama akan disusun sebagai tulang kecil dari tulang utama.

\section{METODE PENELITIAN}

\subsection{Objek dan Variabel Penelitian}

Objek penelitian pada laporan Tugas Akhir adalah kacang garing kualitas first grade yang di produksi oleh PT. XY. Proses produksi yang akan diteliti adalah proses sortir final, yang merupakan proses akhir sebelum kacang dikemas. Waktu produksi kacang garing yang akan diteliti adalah pada 7 Januari 2019 hingga 31 Januari 2019 untuk tiga sift kerja setiap harinya. Terdapat 163 pengambilan sampel untuk diteliti pada jangka waktu tersebut. 
Variabel pertama yaitu kulit kacang pecah (\%), variabel kedua yaitu kacang biji $1(\%)$, dan variabel ketiga adalah kulit kacang busam $\geq 50 \%(\%)$

\subsection{Sumber dan Metode Pengumpulan Data}

Dalam penyusunan laporan Tugas Akhir ini data yang digunakan adalah data sekunder. Data sekunder merupakan data yang diperoleh dari sumber yang telah tersedia. Meliputi data defect, pengambilan data yang dilakukan setiap hari oleh petugas Quality Control (QC) proses sortir final mulai tanggal 7 Januari 2019 sampai tanggal 31 Januari 2019 dan Data sebab-akibat, pengamatan proses kerja praktik pembuatan produk kacang garing dan hasil wawancara dari pengawas ataupun pekerja di PT. XY. Metode yang dilakukan dalam mengambil dan memperoleh data adalah metode dokumen. Pada laporan Tugas Akhir ini menggunakan data yang diperoleh dari petugas $Q C$ Induk.

\subsection{Metode Analisis Data}

Tahapan analisis data yang dilakukan sebagai berikut :

1. Mengambil data defect kacang di petugas QC induk.

2. Melakukan input data tiap jenis defect kacang.

3. Melakukan uji normal multivariat.

4. Melakukan uji korelasi.

5. Membuat peta kendali Max-MCUSUM untuk rata-rata dan variansi, dimana nilai CUSUM berturut-turut yakni $\mathrm{M}_{\mathrm{i}}$.

6. Melakukan analisis kapabilitas proses produksi setelah proses terkendali.

7. Melakukan analisis parameter penyebab cacat menggunakan diagram pareto.

8. Melakukan analisis sebab akibat terhadap penyebab cacat paling dominan.

9. Membuat interpretasi dan mengambil kesimpulan.

\section{HASIL DAN PEMBAHASAN}

\subsection{Karakteristik Kualitas Kacang Garing}

Tabel 2. Struktur Data Karakteristik Kacang Garing

\begin{tabular}{ccccc}
\hline Variabel & Rata-rata & Varians & Maksimum & Spesifikasi \\
\hline Kulit Kacang Pecah & $3,0272393 \%$ & 1,0632 & $6 \%$ & Maks 5\% \\
\hline Kacang Biji 1 & $0,8334969 \%$ & 0,0749 & $1,6 \%$ & Maks 1\% \\
\hline Kulit Kacang Busam $\geq 50 \%$ & $2,5085890 \%$ & 0,3138 & $3,65 \%$ & Maks 3\% \\
\hline
\end{tabular}

Berdasarkan Tabel 2 dapat diketahui deskripsi masing-masing karakteristik kualitas produk Kacang Garing kualitas first grade yaitu, secara umum rata-rata kulit kacang pecah, kacang biji 1, dan kulit kacang busam $\geq 50 \%$ berada dibawah standar maksimum yang dimiliki oleh perusahaan. Namun, beberapa titik pengamatan pada ketiga variabel masih berada diluar batas spesifikasi yang ditentukan. Hal ini dapat dilihat melalui nilai maksimum masing-masing variabel. Nilai maksimum pada variabel kulit kacang pecah sebesar $6 \%$, nilai maksimum variabel kacang biji 1 sebesar 1,6\%, dan nilai maksimum pada vaiabel kulit kacang busam sebesar 3,65\% yang berada diatas nilai batas maksimum perusahaan.

\subsection{Pemeriksaan Asumsi Normal Multivariat}

Pengujian menggunakan Mardia Kurtosis and Skewness menggunakan package MVN di apalikasi R. Berdasarkan kriteria keputusan dalam metode tersebut, akan dibandingkan nilai $z_{1,3}$ dengan nilai $\chi_{\frac{3(3+1)(3+2)}{6} ; \alpha=5 \%}^{2}=18,3070$ dan membandingkan nilai $z_{2,3}$ dengan nilai $Z_{0,05 / 2}=1,96$, maka dapat disimpulkan bahwa hipotesis nol diterima karena nilai $z_{1,3}=17,446297<\chi_{3(3+1)(3+2) / 6}^{2}=18,3070$ dan nilai $z_{2,3}=-0,012485<Z_{\frac{0,05}{2}}=1,96$. Hipotesis nol diterima, maka dapat disimpulkan bahwa data karakteristik kualitas produk Kacang Garing mengikuti distribusi normal multivariat sehingga dapat dilanjutkan dalam pembuatan peta kendali Max-MCUSUM 


\subsection{Korelasi antar Karakteristik Kualitas}

Pengujian menggunakan metode Bartlett melalui aplikasi SPSS. Berdasarkan kriteria keputusan dalam metode tersebut akan dibandingkan nilai $\chi_{\text {hitung }}^{2}=10,803$ dengan nilai $\chi_{\text {tabel }}^{2}=7,8147$, sehingga didapatkan keputusan menolak Ho pada variabel kulit kacang pecah, kacang biji 1, dan kulit kacang busam. Kesimpulan dalam pengujian korelasi Bartlett adalah terdapat korelasi antara variabel kulit kacang pecah, kacang biji 1, serta kulit kacang busam. Korelasi terdapat dalam ketiga variabel karakteristik kualitas produk Kacang Garing sehingga proses analisis lebih lanjut menggunakan analisis statistika multivariat.

\subsection{Pembuatan Diagram Kontrol Maximum Multivariate Cumulative Sum}

Diagram dibuat pertama dengan menentukan parameter yang akan digunakan, yaitu parameter $p=3$, rata-rata vektor $\mu_{G}$ atau nilai target dari perusahaan, rata-rata vektor $\mu_{B}$ atau rata-rata dari sampel yang digunakan, serta nilai target matriks kovarians $\boldsymbol{\Sigma}$. Karena perusahaan tidak memiliki standar sigma good, maka nilai didapatkan dari perhitungan matriks varians kovarians dari data pengamatan. Berikut merupakan nilai rata-rata vektor $\mu_{G}$ dan rata-rata vektor $\mu_{B}$.

$$
\mu_{G}=\left[\begin{array}{l}
5 \\
1 \\
3
\end{array}\right], \mu_{B}=\left[\begin{array}{l}
3,0272393 \\
0,8334969 \\
2,5085890
\end{array}\right] \text {. }
$$

Nilai $\boldsymbol{\Sigma}$ dan $\boldsymbol{\Sigma}^{-1}$ didapatkan dari perhitungan matriks varians kovarians dan invers matriks varians kovarians berdasarkan data pengamatan kualitas produk Kacang Garing. Selanjutnya, untuk setiap sampel dihitung $Z_{i}$ dan $Y_{i}$ dengan persamaan (13) dan persamaan (19). Untuk mendapatkan nilai $Z_{i}$, terlebih dahulu menghitung nilai $a^{\prime}$ yang membutuhkan nilai $\left(\boldsymbol{\mu}_{B}-\boldsymbol{\mu}_{G}\right)$ dan $\left(\boldsymbol{\mu}_{B}-\boldsymbol{\mu}_{G}\right)^{\prime}$, serta invers dari matriks varians kovarians yang telah didapat sebelumnya.

$$
\left(\boldsymbol{\mu}_{B}-\boldsymbol{\mu}_{G}\right)=\left[\begin{array}{l}
-1,9727607 \\
-0,1665031 \\
-0,4914110
\end{array}\right],\left(\boldsymbol{\mu}_{B}-\boldsymbol{\mu}_{G}\right)^{\prime}=\left[\begin{array}{lll}
-1,9727607 & -0,1665031 & -0,4914110
\end{array}\right],
$$

Setelah didapatkan nilai dari seluruh komponen pembentuk nilai $a^{\prime}$, maka dilakukan perhitungan nilai $a^{\prime}$ dengan hasil sebagai berikut.

$$
a^{\prime}=\frac{\left(\boldsymbol{\mu}_{B}-\boldsymbol{\mu}_{G}\right) \boldsymbol{\Sigma}^{-1}}{\left[\left(\boldsymbol{\mu}_{B}-\boldsymbol{\mu}_{G}\right) \boldsymbol{\Sigma}^{-1}\left(\boldsymbol{\mu}_{B}-\boldsymbol{\mu}_{G}\right)\right]^{1 / 2}}=\left[\begin{array}{lll}
-0,8966627 & -0,7302708 & -0,9391181
\end{array}\right] .
$$

Nilai $a^{\prime}$ merupakan komponen dari perhitungan nilai $Z_{i}$. Nilai $Z_{i}$ akan dihitung dengan contoh data pengamatan pertama, yaitu $X_{1}^{\prime}=\left[\begin{array}{lll}3,17 & 0,87 & 1,25\end{array}\right]$. Nilai $Z_{i}$ didapat melalui mengkalikan nilai $a^{\prime}$ yang telah didapatkan dengan selisih antara data pengamatan pertama dan nilai rata-rata baik. Berikut merupakan perhitungan nilai $Z_{i}$ untuk data pengamatan pertama kualitas produk Kacang Garing PT XY.

$$
Z_{1}=a^{\prime}\left(\boldsymbol{X}_{1}-\boldsymbol{\mu}_{G}\right)=3,37928456 .
$$

Setelah didapatkan nilai $Z_{i}$, selanjutnya dilakukan perhitungan untuk nilai $Y_{i}$ sesuai dengan persamaan (2.25). Maka, didapatkan nilai $Y_{i}$ untuk data pengamatan pertama sebagai berikut.

$$
Y_{1}=\phi^{-1}\left\{H\left[\left(\boldsymbol{X}_{1}-\boldsymbol{\mu}_{G}\right)^{\prime} \boldsymbol{\Sigma}^{-1}\left(\boldsymbol{X}_{1}-\boldsymbol{\mu}_{G}\right) ; p\right]\right\}=3,01960314 .
$$

Nilai $Z_{1}$ sebesar 3,37928456 dan $Y_{1}$ sebesar 3,01960314, dilanjutkan dengan menghitung nilai $\mathrm{k}$ dan $\mathrm{D}$ pada persamaan (11) dan persamaan (12). Berikut hasil perhitungan nilai $\mathrm{k}$ dan $\mathrm{D}$.

$$
k=0,5 \frac{\left(\boldsymbol{\mu}_{B}-\boldsymbol{\mu}_{G}\right) \boldsymbol{\Sigma}^{-1}\left(\boldsymbol{\mu}_{B}-\boldsymbol{\mu}_{G}\right)}{\left[\left(\boldsymbol{\mu}_{B}-\boldsymbol{\mu}_{G}\right) / \boldsymbol{\Sigma}^{-1}\left(\boldsymbol{\mu}_{B}-\boldsymbol{\mu}_{G}\right)\right]^{1 / 2}}=1,175993, D=\sqrt{\left(\boldsymbol{\mu}_{B}-\boldsymbol{\mu}_{G}\right)^{\prime} \boldsymbol{\Sigma}^{-1}\left(\boldsymbol{\mu}_{B}-\boldsymbol{\mu}_{G}\right)}=2,351986
$$

Langkah selanjutnya adalah menentukan titik-titik plot mean dan varians dengan menghitung cumulative sum $C_{i}^{+}, C_{i}^{-}, S_{i}^{+}$, dan $S_{i}^{-}$. Nilai maksimum dari $C_{i}^{+}$dan $C_{i}^{-}$digunakan 
untuk memonitor rata-rata proses sesuai dengan persamaan (20) dan (21). Perhitungan $C_{i}^{+}$ dan $C_{i}^{-}$untuk data pertama adalah sebagai berikut.

$C_{1}^{+}=\max \left(0 ; Z_{1}-0,5 D+C_{0}^{+}\right)=2,203291, C_{1}^{-}=\max \left(0 ;-0,5 D-Z_{1}+C_{0}^{-}\right)=0$

Nilai maksimum dari $C_{i}^{+}$sebesar 2,203291 dan $C_{i}^{-}$sebesar 0 adalah 2,203291 sebagai pergeseran rata-rata proses pada pengamatan pertama. Pergeseran proses varian dimonitor melalui nilai maksimum dari $S_{i}^{+}$, dan $S_{i}^{-}$sesuai dengan persamaan (22) dan (23), maka dapat diketahui $S_{i}^{+}$, dan $S_{i}^{-}$untuk data pengamatan pertama adalah sebagai berikut.

$$
S_{1}^{+}=\max \left(0 ; Y_{1}-k+S_{0}^{+}\right)=1,843610, S_{1}^{-}=\max \left(0 ;-k-Y_{1}+S_{0}^{-}\right)=0
$$

Nilai $S_{i}^{+}$sebesar 1,843610 dan $S_{i}^{-}$sebesar 0 sehingga nilai maksimum adalah 1,843610 sebagai pergeseran varian proses pada pengamatan pertama. Karena pada prosedur pengendalian kualitas multivariat dilakukan monitoring pada besarnya pergeseran bukan arahnya, sehingga dilakukan transformasi sesuai persamaan (24) dan (25) dengan hasil sebagai berikut.

$$
C_{1}=\max \left(C_{1}^{+} ; C_{1}^{-}\right)=2,203291, S_{1}=\max \left(S_{1}^{+} ; S_{1}^{-}\right)=1,843610
$$

Nilai $C_{i}$ dan $S_{i}$ yang telah didapatkan akan digunakan untuk menghitung nilai $M_{i}$, yaitu nilai yang akan diplotkan pada diagram kontrol Max-MCUSUM. Nilai $M_{i}$ merupakan nilai maksimum antara nilai $C_{i}$ dan $S_{i}$ sesuai dengan persamaan (26). Berikut merupakan hasil perhitungan nilai $M_{i}$ untuk data pengamatan pertama.

$$
M_{1}=\max \left(C_{1} ; S_{1}\right)=2,203291
$$

Berdasarkan hasil tersebut, didapatkan nilai maksimum antara nilai $C_{i}$ dan $S_{i}$ adalah sebesar 2,203291. Selanjutnya, dilakukan perhitungan yang sama untuk data pengamatan lainnya hingga data ke-163 sehingga terbentuk nilai $M_{i}$ untuk diagram kontrol MaxMCUSUM.

\subsection{Penentuan Batas Kendali Atas}

Nilai batas kendali atas (h) pada penelitian didapatkan melalui simulasi dengan menggunakan $\alpha$ sebesar 0,0027, yang merupakan batas diagram kontrol three-sigma yang sarankan oleh Shewhart, sehingga nilai ARL atau (Average Run Length) yang digunakan sebesar $\frac{1}{\alpha}=\frac{1}{0,0027}=370$ (Mitra, 2008). Nilai batas kendali atas sebasar 429,69 karena nilai ARL yang dikehendaki adalah 370,00, sehingga nilai batas kendali atas (h) yang akan digunakan pada pengendalian kualitas produk Kaacang Garing menggunakan diagram kontrol Max-MCUSUM adalah sebesar 429,69.

\subsection{Pengendalian Kualitas Produk Kacang Garing}

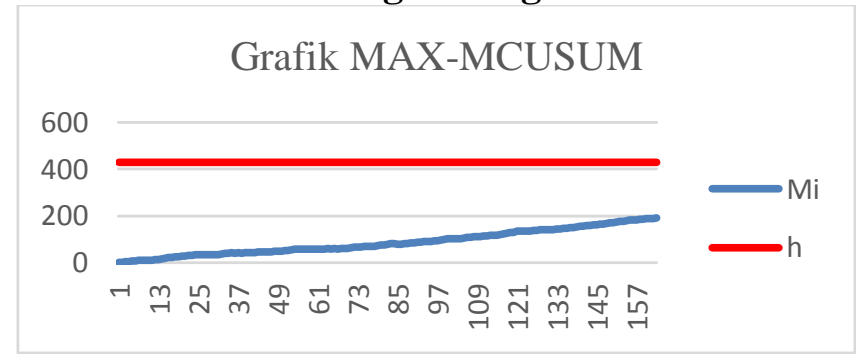

Gambar 1. Diagram Kontrol Max-MCUSUM

Secara visual Gambar 1 menunjukan banyaknya pengamatan yang diamati pada sumbu horizontal dan nilai $M_{i}$ diplotkan pada sumbu vertical. Garis horizontal berwarna merah merupakan batas kendali atas (h) sebesar 429,69 yang merupakan hasil simulasi menggunakan ARL 370 serta rata-rata dan matriks varians kovarians yang sama dengan data pengamatan produk Kacang Garing pada tanggal 7 Januari hingga 31 Januari 2019. Berdasarkan Gambar 1, dapat dilihat bahwa diagram kontrol Max-MCUSUM kualitas produk Kacang Garing dengan batas kendali atas (h) sebesar 426,69 telah terkendali secara statistik. Nilai maksimum $M_{i}$ adalah sebesar 191,6869 sehingga tidak tersapat titik 
pengamatan $\left(M_{i}\right)$ yang berada di atas intervalkeputusan $(\mathrm{h})$, sehingga dapat disimpulkan bawaha kualitas produk Kacang Garing menggunakan diagram kontrol Max-MCUSUM telah terkendali secara statistik.

\subsection{Analisis Kapabilitas Proses}

Perusahaan tidak menetapkan bobot tertentu di antara karakteristik kualitas Kacang Garing, maka digunakan bobot yang sama untuk kulit kacang pecah, kacang biji 1, dan kulit kacang busam $\geq 50 \%$ yaitu 0,333 .

Tabel 3. Nilai Kapabilitas Proses

\begin{tabular}{lccccc}
\hline \multicolumn{1}{c}{ Variabel } & $w_{i}$ & $C_{p}$ & $C_{p k}$ & $M C_{p}$ & $M C_{p k}$ \\
\hline Pecah & 0,333 & 1,07 & 1,30 & & \\
Biji 1 & 0,333 & 0,63 & 1,06 & 0,905 & 1,355 \\
Busam $>50 \%$ & 0,333 & 1,02 & 1,71 & & \\
\hline
\end{tabular}

Proses dikategorikan kapabel secara univariat apabila memiliki nilai $C_{p}$ karakteristik kualitas lebih dari 1, sehingga dapat dikatakan bahwa kulit kacang pecah dan kulit kacang busam $\geq 50 \%$ telah kapabel, akan tetapi kacang biji 1 memiliki nilai $C_{p}$ yang jauh kurang dari 1 sehingga proses belum kapabel berdasarkan nilai $C_{p}$. Nilai $M C_{p}$ mendekati nilai 1 menunjukan bahwa secara multivariat dengan pembobotan yang sama kinerja proses memiliki kapabilitas yang sedikit kurang. Perhitungan nilai $C_{p k}$ menunjukan bahwa ketiga karakteristik kualitas bernilai lebih 1, sehingga secara univariat memiliki akurasi yang tinggi. Nilai $M C_{p k}$ dengan pembobotan yang sama, didapatkan nilai lebih 1 sehingga dapat disimpulkan bahwa dari segi akurasi proses dikatakan memiliki kinerja yang baik. Nilai tersebut menunjukan bahwa produk Kacang Garing sudah memenuhi spesifikasi kualitas yang ditetapkan oleh PT XY.

\subsection{Analisis Karakteristik Kualitas dengan Diagram Pareto}

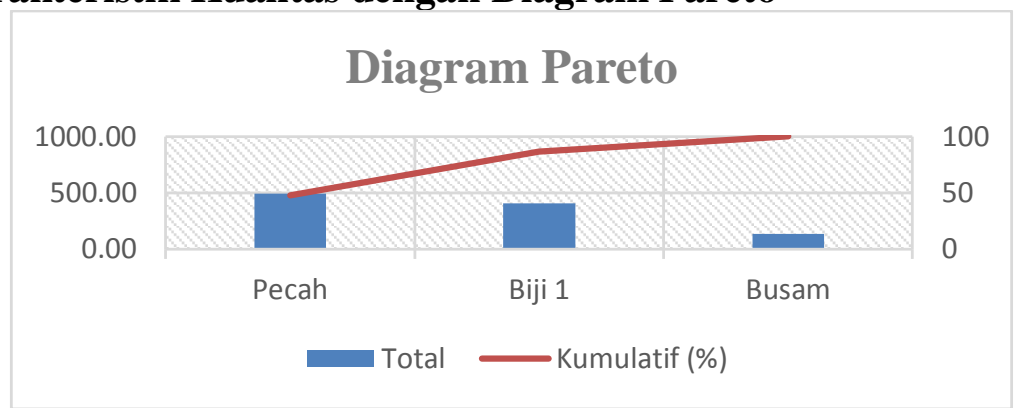

Gambar 2. Diagram Pareto

Kacang Garing berada dalam sumbu horizontal dan banyaknya kejadian cacat dalam sumbu vertikal. Garis Data karakteristik kualitas berupa percent sehingga jumlah atau total kejadian cacat berpa penjumlahan percent kejadian cacat setiap pengambilan sampel. Kejadian cacat yang diakibatkan oleh kulit kacang pecah menjadi penyebab yang paling dominan dengan total kejadian sebesar 493,44, kemudian cacat dikarenakan kulit kacang busam $\geq 50 \%$ sebesar 408,9, dan cacat dikarenakan kacang biji sebesar 135,86 kejadian dari 163 pengambilan sampel yang dilakukan. Hasil diatas menunjukan bahwa kulit kacang pecah menjadi penyebab cacat yang paling dominan sehingga dapat dilakukan analisis sebab-akibat.

\subsection{Analisis Karakteristik Kualitas dengan Diagram Sebab-akibat}

Faktor penyebab utama dalam diagram sebab-akibat, yaitu mesin (machine), bahan baku (material), dan metode (method). Potensi faktor-faktor penyebab terjadinya kecacatan kulit kacang pecah didasarkan pada hasil diskusi Bersama Karu Sortir Final Kacang Garing kualitas first grade dan tenaga kerja QC sortir final Kacang Garing kualitas first grade. 


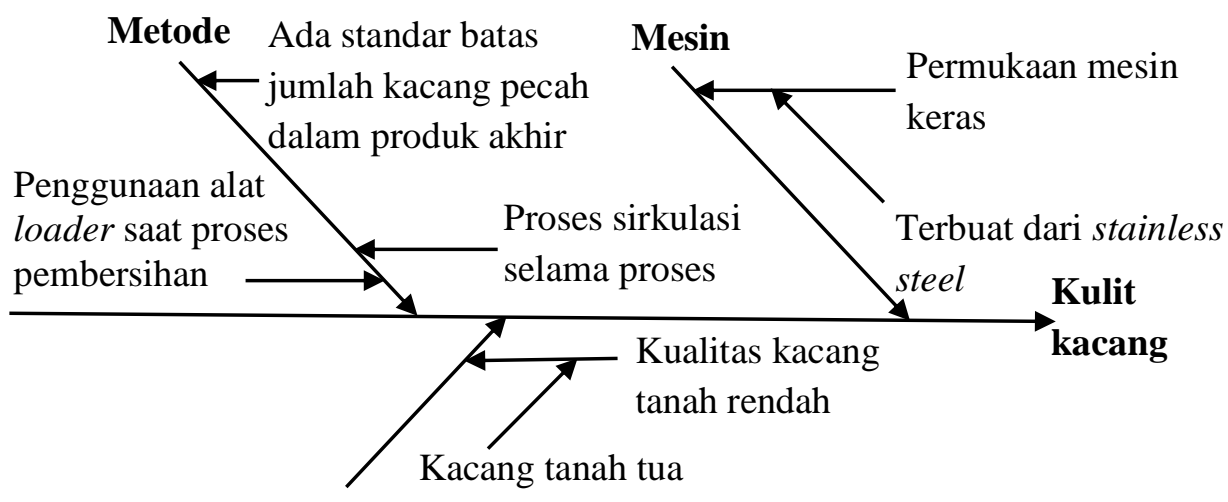

Bahan

Gambar 3. Diagram Sebab-akibat

\section{KESIMPULAN}

Pada diagram kendali Max-MCUSUM diperoleh nilai tertinggi $M_{i}$ adalah sebesar 191,6869 dan batas kendali atas (h) dengan nilai ARL sebesar 370 adalah 429,69. Plot berada dibawah batas kendali atas sehingga proses sudah terkendali. Nilai $M C_{p}$ sebesar 0,905 menunjukan bahwa secara multivariat proses memiliki kapabilitas yang kurang. Nilai $M C_{p k}$ sebesar 1,355 dapat disimpulkan bahwa dari segi akurasi proses dikatakan memiliki kinerja yang baik. Nilai tersebut menunjukan bahwa produk Kacang Garing sudah memenuhi spesifikasi kualitas yang ditetapkan oleh PT XY.

\section{DAFTAR PUSTAKA}

Assauri, S. 1998. Manajemen Produksi dan Operasi. Jakarta: Lembaga Penerbit Fakultas Ekonomi Universitas Indonesia.

Cheng, S. W., \& Thaga, K. 2005. "Multivariate Max-MCUSUM Chart". Quality

Technology \& Quantitative Management, Vol. 10, 221-235.

Haryatmi, S. dan Guritno, S. 2008. Metode Statistika Multivariat. Jakarta: Universitas Terbuka.

Meghan, K. C., Zhiyong, Z., \& Ke-Hai, Y. 2017. "Univariate and Multivariate skewness and Kurtosis for Measuring Nonnormality: Prevelance, Influence and Estimation". Behav Res, 49: 1716-1735.

Mitra, A. 2008. Fundamentals of Quality Control and Improvement, Third Edition. New Jersey: John Wiley and Sons Inc.

Montgomery, D. 2009. Statistical Quality Control, Sixth Edition. Singapore: John Wiley and Sons Inc.

Montgomery, D. 2013. Introduction to Statistical Quality Control, $8^{\text {th }}$ Edition. New York: John Wiley and Sons Inc.

Muirhead, R. 1982. Aspect of Multivariate Statistical Theory. New York: John Wiley and Sons Inc.

Raissi, S. 2009. "Multivariate Process Capability Indices on The Presence of Priority for Quality Characteristics". Journal of Industrial Engineering International, Vol. 5 No. 9, 27-36

Wilkinson, L. 2006. "Revising the Pareto Chart". The American Statistician, Vol. 60 No. 4, 332-334. 